\title{
PENGEMBANGAN PERMAINAN LUDO KING OF ACCOUNTING (DOTING) SEBAGAI MEDIA PENGAYAAN PADA MATERI JURNAL KHUSUS PERUSAHAAN DAGANG
}

\author{
Titik Fauziati $^{1}$, Joni Susilowibowo ${ }^{2}$ \\ ${ }^{1}$ Universitas Negeri Surabaya, ${ }^{2}$ Universitas Negeri Surabaya \\ ${ }^{1}$ titikfauziati16080304065@mhs.unesa.ac.id, ${ }^{2}$ jonisusilowibowo@unesa.ac.id
}

\begin{abstract}
This research was conducted with the aim of analyzing the development process and analyzing the feasibility of the ludo king of accounting game which was developed as an enrichment media in special journal material for trading company class XI Accounting in SMK Negeri 1 Sooko Mojokerto. The development model in this study is the ADDIE model which includes the Analyze, Design, Development, Implementation, and Evaluation stages. However, the implementation and evaluation stages in the ADDIE development model were not carried out due to certain conditions and time constraints. The test subjects in the research are material experts and media experts. The instrument used for data collection in the form of a study sheet in the form of an open questionnaire and a sheet of validasi in the form of a closed questionnaire. The method used to analyze data from study sheets and validation of material and media was carried out in a quantitative descriptive manner based on a Likert scale. The results obtained in the form of the feasibility of the material which shows the average percentage of material validation results of $87,71 \%$ with a very decent category and the percentage of results of the media validation of $88 \%$ with a very decent category. Thus, the game of ludo king of accounting is declared to be very suitable to be used as enrichment media in special journal material for trading companies of class XI Accounting.
\end{abstract}

Keywords: Enrichment Media, Ludo King of Accounting Game, ADDIE Development Model.

\section{Pendahuluan}

Pendidikan merupakan pondasi yang menjadi dasar bagi kelangsungan hidup suatu bangsa. Pendidikan dijadikan sebagai alat untuk menciptakan suasana dan proses belajar yang lebih baik guna mengembangkan potensi, pengetahuan, keterampilan, dan membentuk kepribadian yang ada dalam diri peserta didik. Sebagaimana yang termuat dalam UU No. 20 Tahun 2003 Pasal 1 Ayat (1) mengenai Sistem Pendidikan Nasional yang menjelaskan bahwa suatu pendidikan merupakan usaha yang secara terencana dilakukan demi menciptakan suasana dan proses belajar bagi peserta didik yang lebih hidup, sehingga potensi dalam diri peserta didik dapat berkembang, memiliki kepribadian, akhlak bermutu, dan keterampilan yang bermanfaat untuk masyarakat dan bangsa maupun negara.

Berdasarkan hal tersebut, pemerintah terus berupaya untuk mengembangkan pendidikan yang ada di Indonesia. Salah satu upaya yang dapat dilakukan melalui pengembangan kurikulum yang ada pada sekolah. Sekolah ialah bentuk lembaga pendidikan yang bersifat formal. Hamalik (2015) menyatakan bahwa sebagai lembaga pendidikan formal, sekolah harus membuat berbagai rencana yang ada dalam lingkungan pendidikan yang akan disusun dan ditata dalam suatu kurikulum dan dilaksanakan pada proses pembelajaran agar dapat memberikan kesempatan belajar bagi peserta didik. Menurut Nasution (2012) kurikulum adalah semua rencana yang disusun dan dibuat dengan tujuan untuk melancarkan kegiatan pembelajaran yang berada di dalam tanggung jawab dan pengawasan sekolah, lembaga pendidikan maupun staf yang mengajar.

Kurikulum 2013 revisi tahun 2018 adalah kurikulum yang saat ini berlaku di Indonesia dan merupakan kurikulum penyempurna dari kurikulum sebelumnya. Standar penilaian yang diterapkan dalam kurikulum 2013 revisi yaitu standar penilaian otentik. Sebagaimana yang termuat pada Permendikbud No. 23 Tahun 2016 tentang Standar Penilaian Pendidikan yang

DOI: 10.33603/ejpe.v9i1.4327

This is an open access article under the CC-BY-SA license 
mengemukakan bahwa penilaian otentik seluruh hasil belajar peserta didik meliputi tiga aspek, yaitu sikap, pengetahuan, dan keterampilan. Peserta didik dituntut agar mencapai KKM atau Kriteria Ketuntasan Minimal yang telah ditetapkan dalam kurikulum 2013 revisi. Dengan demikian, diperlukan adanya program perbaikan dan pengayaan bagi peserta didik. Dalam Permendikbud No. 22 Tahun 2016 terkait Standar Proses Pendidikan Dasar dan Menengah menjelaskan bahwa ketika merancangkan program remidial, pengayaan, dan bimbingan konseling bagi peserta didik dapat dilakukan berdasarkan hasil dari penilaian otentik.

Program pengayaan ialah pembelajaran yang diperuntukkan bagi peserta didik yang nilainya sudah mencapai KKM yang telah ditentukan. Program pengayaan dilakukan untuk memberikan kesempatan belajar baru bagi peserta didik yang bertujuan agar peserta didik mampu mengembangkan dan mengoptimalkan minat, bakat, dan kecakapannya terhadap kegiatan pembelajaran. Kegiatan pengayaan dapat dilaksanakan melalui berbagai cara seperti memberikan latihan soal dengan tingkat kesulitan yang lebih tinggi, penerapan media untuk menunjang kegiatan pengayaan, dan lain sebagainya agar peserta didik lebih antusias, terampil dalam memecahkan masalah, dan mampu mencapai kapasitas belajar yang optimal.

Media pembelajaran adalah suatu perangkat yang dipergunakan sebagai perantara guna membantu kegiatan pembelajaran dalam menyajikan materi yang lebih menarik dan membuat kondisi belajar menjadi menyenangkan. Belajar menyenangkan menurut Rahman \& Amri (2013) yaitu peserta didik belajar tanpa adanya perasaan tertekan (joyfull learning). Hamalik (2016) menyatakan bahwa teknik dan proses belajar mengajar yang dilakukan secara bervariasi, seperti belajar sambil bermain dengan alat permainan akan mewujudkan suasana belajar menjadi lebih seru dan menyenangkan. Melalui adanya penerapan media dalam kegiatan pembelajaran akan memperlancar interaksi antar peserta didik dengan guru maupun dengan peserta didik lainnya. Sehingga kegiatan pembelajaran yang dilaksanakan dapat berjalan secara efektif dan efisien.

Media pembelajaran ialah suatu instrumen atau medium yang dimanfaatkan dalam menunjang kegiatan pembelajaran untuk menumbuhkan pemikiran, perasaan, kemampuan, dan keterampilan dalam diri peserta didik agar dapat menstimulasikan terjadinya proses belajar sehingga tujuan pembelajaran yang telah dirumuskan dapat tercapai. Sebagaimana yang dikemukakan oleh Arsyad (2017) media adalah alat yang dapat digunakan untuk menunjang proses belajar dalam mengantarkan informasi dan pengetahuan. Media berguna dalam menunjang kegiatan belajar di kelas agar menjadi lebih menyenangkan yaitu media jenis permainan. Menurut Sakinah \& Iswendi (2018) permainan dapat dimanfaatkan sebagai alternatif media dalam menunjang kegiatan pembelajaran untuk meningkatkan aktivitas peserta didik dalam mengerjakan latihan soal. Sadiman (2011) menyebutkan bahwa kelebihan permainan sebagai media pendidikan adalah permainan bersifat menghibur dan menyenangkan ketika dilakukan, permainan bersifat luwes, permainan berpotensi menumbuhkan partisipasi aktif peserta didik dalam belajar, memberikan umpan balik, memungkinkan adanya penerapan konsep secara nyata dalam kehidupan dimasyarakat, dan permainan juga sederhana untuk dijalankan, ditemukan, diproduksi, dan digandakan.

Pada proses pembelajaran khususnya dalam kegiatan pengayaan terdapat berbagai macam media yang dapat dimanfaatkan. Salah satunya yaitu media jenis permainan yang dapat menunjang kegiatan pengayaan agar menjadi lebih menyenangkan. Sadiman (2011) mengemukakan bahwa media jenis permainan merupakan suatu alat atau perantara yang bersifat menyenangkan dan menghibur untuk dilakukan. Menurut Tiarto, Suyatna, \& Sesunan, (2013) penggunaan permainan dapat melibatkan peserta didik dalam pembelajaran aktif, memberikan perasaan gembira, dan menambah motivasi dalam diri peserta didik. Media 
pengayaan berupa permainan akan menarik perhatian dan minat peserta didik dalam melaksanakan kegiatan pengayaan bersama teman-temannya, baik itu kegiatan pengayaan yang dilakukan secara individu maupun kelompok. Suatu permainan dikatakan menarik karena dalam permainan memiliki unsur kompetisi antar setiap pemain untuk menentukan siapa pemain yang kalah dan siapa yang memenangkan permainan tersebut. Sadiman (2011) juga menyatakan bahwa penggunaan media yang dilaksanakan dengan berkelompok dapat melatih peserta didik untuk berdiskusi tentang materi yang sedang dipelajari.

Dari hasil wawancara yang telah dilakukan oleh peneliti bersama salah satu Guru Akuntansi yang mengajar di 3 kelas XI Akuntansi dan beberapa peserta didik kelas XI-AKL di SMK Negeri 1 Sooko Mojokerto, diperoleh informasi bahwa nilai ulangan harian peserta didik pada materi jurnal khusus perusahaan dagang kelas XI Akuntansi di semester genap tahun ajaran 2019-2020 menunjukkan 17\% peserta didik nilainya dibawah KKM, 19\% peserta didik telah tuntas dengan nilai diambang batas, dan sisanya $64 \%$ peserta didik telah tuntas dengan nilai di atas KKM. Jumlah peserta didik yang telah tuntas jauh lebih banyak yaitu 84 peserta didik yang telah tuntas dari total 101 total peserta didik kelas XI Akuntansi bila dibandingkan peserta didik yang belum tuntas. Sehingga, peserta didik yang telah tuntas penting untuk diberikan kegiatan pengayaan agar peserta didik tersebut dapat meningkatkan dan memperdalam pemahaman serta penguasaan peserta didik terhadap materi jurnal khusus perusahaan dagang.

Selain itu, diperoleh informasi bahwa kegiatan pengayaan yang ada di kelas cenderung dilakukan dengan cara mengerjakan soal latihan yang ada dalam buku maupun soal latihan yang telah dibuat oleh guru berupa lembar foto copy. Media yang biasa dimanfaatkan ketika melakukan kegiatan pengayaan di kelas hanya terbatas pada penggunaan LCD-powerpoint dan papan tulis. Belum ada penggunaan media yang bervariatif dalam menunjang kegiatan pengayaan di kelas. Penggunaan media yang kurang bervariatif ini menyebabkan peserta didik merasa jenuh, tidak antusias, dan kurang termotivasi dalan melaksanakan kegiatan pengayaan. Bahkan masih terdapat peserta didik yang cenderung sibuk berbicara sendiri dengan temannya saat mengikuti kegiataan pengayaan. Sehingga peserta didik memiliki motivasi yang rendah dalam melaksanakan kegiatan pengayaan dan kegiatan pengayaan yang seharusnya dilakukan untuk mengoptimalkan kemampuan peserta didik dalam kegiatan belajar menjadi tidak optimal lagi. Maka dari itu, diperlukan adanya fasilitas dari guru yang diperuntukkan bagi peserta didik berupa media yang menarik dan bervariatif untuk menunjang kegiatan pengayaan agar peserta didik yang melakukan kegiatan pengayaan dapat termotivasi dalam mengoptimalkan kemampuannya.

Berdasarkan informasi di atas, maka diperlukan adanya pengembangan media pengayaan yang bervariasi dan tepat untuk materi jurnal khusus perusahaan dagang. Dengan demikian, peneliti berupaya mengembangkan permainan ludo king sebagai media pengayaan untuk materi jurnal khusus perusahaan dagang. Menurut Ningsih \& Pritandhari (2019) pemilihan permainan ludo king sebagai media pengayaan dapat memberikan suasana belajar yang menyenangkan bagi peserta didik. Kelebihan permainan ludo king sebagai media pengayaan yaitu permainan ludo king bersifat kompetitif, didesain sesuai dengan kebutuhannya sebagai media pengayaan, berupa media cetak yang dikemas dengan praktis dan mudah dibawa. Media permainan ludo king juga dimodifikasi dengan penambahan berbagai jenis kartu, mulai dari kartu soal, kartu jawaban, dan kartu permainan, serta dilengkapi dengan aturan main.

Permainan yang dikembangkan dalam penelitian ini berupa permainan ludo king. Ludo king adalah permainan tradisional yang berasal dari India. Menurut Jannah \& Wiyatmo (2018) 
permainan ludo king merupakan permainan jenis board game dengan desain papan permainan berpetak dan dimainkan oleh 2 sampai 4 orang yang saling berkompetisi dalam menjalankan pion berdasarkan lemparan dadu dimulai dari start hingga menuju finish. Permainan ludo king dijalankan dengan menggunakan papan ludo king dalam bentuk cetak, pion, dan dadu. Selain itu, permainan ludo king sebagai media pengayaan juga dilengkapi dengan beberapa kartu soal, jawaban, dan kartu permainan. Setiap pemain saling berkompetisi menjadi yang tecepat sampai finish dengan mengumpulkan poin terbanyak.

Media permainan ludo king sebagai media pengayaan memuat beberapa latihan soal terkait materi jurnal khusus perusahaan dagang. Soal dalam media permainan ludo king dibuat bervariasi dengan tingkat kesulitan yang lebih tinggi dan disesuaikan dengan indikator. Dengan adanya media permainan ludo king, peserta didik dapat belajar sambil bermain, menjadi lebih antusias dan bersemangat dalam melaksanakan kegiatan pengayaan. Selain itu, melalui media permainan ludo king peserta didik dapat berkompetisi untuk merebut kemenangan dan saling berinteraksi dengan satu sama lain sepanjang kegiatan pembelajaran berlangsung. Sebagaimana yang dikemukan oleh Sakinah \& Iswendi (2018) bahwa dengan adanya media permainan, peserta didik akan berlomba untuk memenangkan permainan tersebut, sehingga peserta didik dapat terlibat secara aktif dalam proses pembelajaran saat mengerjakan soal latihan. Dengan demikian peserta didik dapat meningkatkan kemampuannya dan memperluas pemahaman terhadap materi jurnal khusus perusahaan dagang melalui soal pengayaan yang disajikan dalam media permainan ludo king.

Angguntari (2019) dalam penelitiannya menjelaskan bahwa papan permainan ludo sebagai media pengayaan dinyatakan layak digunakan pada kompetensi dasar menganalisis persyaratan personil administrasi, serta dapat memotivasi peserta didik untuk semangat belajar. Khodizah (2019) juga menyatakan bahwa pengembangan produk media pengajaran fisika dalam bentuk permainan ludo layak digunakan sebagai media pengayaan. Selain itu, penelitian serupa yang dilakukan oleh Yolanda \& Iswendi (2019) juga menjelaskan bahwa permainan ludo yang digunakan sebagai media pengayaan pada materi bentuk molekul dinyatakan layak. Persamaan produk pada penelitian ini dengan penelitian Angguntari, Khodizah, dan Yolanda yaitu sama-sama memanfaatkan permainan ludo sebagai media. Perbedaannya ada pada desain permainan, aturan main, dan modifikasi permainan ludo yang berisi soal-soal pengayaan terkait materi jurnal khusus perusahaan dagang.

Berdasarkan penjabaran di atas, peneliti berupaya untuk mengembangkan media pengayaan berupa permainan ludo king dalam kegiatan pembelajaran melalui penelitian pengembangan dengan judul "Pengembangan Permainan Ludo King of Accounting (Doting) sebagai Media Pengayaan pada Materi Jurnal Khusus Perusahaan Dagang". Adapun permasalahan yang dapat dirumuskan dari penjabaran di atas adalah (1) Bagaimana proses pengembangan permainan ludo king of accounting sebagai media pengayaan pada materi jurnal khusus perusahaan dagang? (2) Bagaimana kelayakan permainan ludo king of accounting sebagai media pengayaan pada materi jurnal khusus perusahaan dagang? Sehingga, dari masalah yang telah dirumuskan tersebut, penelitian ini bertujuan untuk (1) Menganalisis proses pengembangan permainan ludo king of accounting sebagai media pengayaan pada materi jurnal khusus perusahaan dagang. (2) Menganalisis kelayakan permainan ludo king of accounting sebagai media pengayaan pada materi jurnal khusus perusahaan dagang. 


\section{Metode Penelitian}

Jenis penelitian ini yaitu penelitian R\&D (Reseacrh and Development) yang mengimplementasikan model ADDIE (Analyze, Design, Development, Implementation, and Evaluation) dalam pengembangan media pengayaan permainan ludo king of accounting terkait materi jurnal khusus perusahaan dagang. Menurut Molenda (2003) terdapat lima tahapan dalam model pengembangan ADDIE yaitu tahap analisis, perancangan, pengembangan, implementasi, dan tahap evaluasi. Namun penelitian ini hanya dilakukan sampai pada tahap pengembangan. Hal ini dikarenakan adanya keterbatasan waktu dan kondisi tertentu. Sehingga, tahap implementasi dan evaluasi tidak dilakukan. Adapun model pengembangan ADDIE beserta tahapannya dapat digambarkan dalam diagram pada Gambar 1. sebagai berikut:

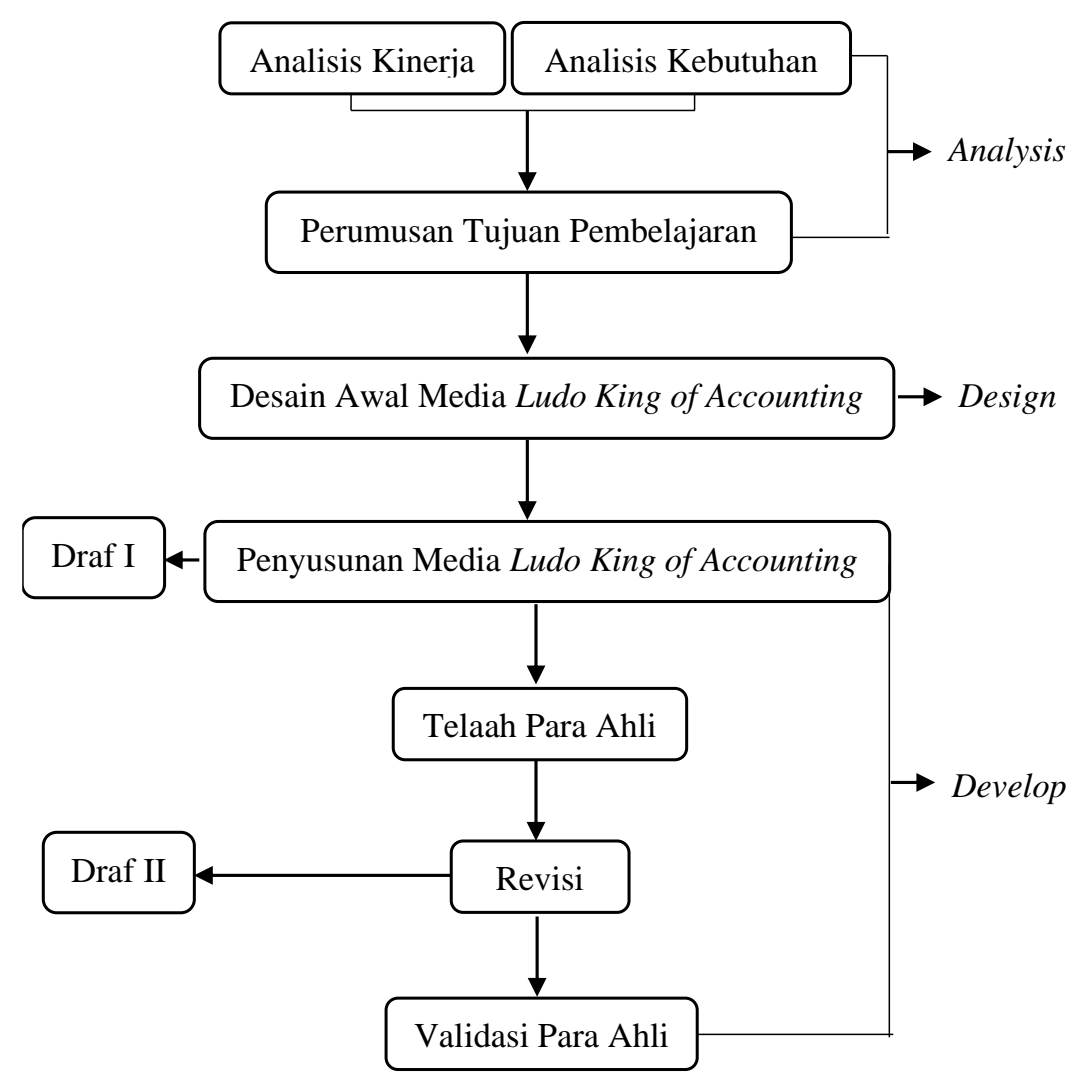

Gambar 1.

Prosedur Pengembangan Media Pengayaan Ludo King of Accounting Model ADDIE

Sumber: dikembangkan oleh peneliti (2020) dengan adaptasi dari Molenda (2003)

Validator dalam penelitian mencakup ahli materi yang merupakan seorang Guru Akuntansi di SMK dan Dosen Pendidikan Akuntansi, dan ahli media yang merupakan seorang Dosen Kurikulum dan Teknologi Pendidikan. Jenis data yang digunakan dalam penelitian ini berupa data kualitatif yang diperoleh melalui hasil telaah dari instrumen data berupa lembar telaah materi dan lembar telaah media dalam bentuk angket terbuka dan data kuantitatif yang dihitung berdasarkan hasil validasi yang dilakukan oleh para ahli dengan instrumen pengumpulan data berupa lembar validasi dalam bentuk angket tertutup. Selanjutnya, data yang diperoleh akan dianalisis menggunakan teknik analisis deskriptif kuantitatif berdasarkan skala likert dalam bentuk persentase skor. 
Tabel 1. Kriteria Skor Skala Likert

\begin{tabular}{cc}
\hline Kriteria & Nilai/Skor \\
\hline Sangat Baik & 5 \\
Baik & 4 \\
Sedang & 3 \\
Buruk & 2 \\
Buruk Sekali & 1 \\
\hline
\end{tabular}

Sumber: (Riduwan, 2012)

Perhitungan hasil validasi dilakukan dengan cara berikut:

$\begin{aligned} & \text { Persentase Nilai } \\ & \text { Kelayakan }(\%)\end{aligned}=\frac{\text { Jumlah Skor Total }(\mathrm{x})}{\text { Skor Maksimal }\left(\mathrm{x}_{\mathrm{i}}\right)} \quad \mathrm{x} 100 \%$

Persentase kelayakan permainan ludo king of accounting sebagai media pengayaan yang telah diperoleh dari hasil perhitungan di atas, selanjutnya akan diinterpretasikan berdasarkan kriteria interpretasi skor kelayakan pada tabel berikut:

Tabel 2. Kriteria Interpretasi

\begin{tabular}{cc}
\hline Penilaian & Kriteria Interpretasi \\
\hline $0 \%-20 \%$ & Sangat Tidak Layak \\
$21 \%-40 \%$ & Tidak Layak \\
$41 \%-60 \%$ & Cukup Layak \\
$61 \%-80 \%$ & Layak \\
$81 \%-100 \%$ & Sangat Layak \\
\hline
\end{tabular}

Sumber: (Riduwan, 2012)

Berdasarkan kriteria interpretasi di atas, maka permainan ludo king of accounting yang dijadikan sebagai media pengayaan pada materi jurnal khusus perusahaan dagang layak digunakan apabila persentase hasil kelayakan yang diperoleh mencapai rata-rata $\geq 61 \%$ sehingga kriteria interpretasi menunjukkan kata layak maupun sangat layak.

\section{Hasil dan Pembahasan \\ Hasil Penelitian}

Hasil penelitian ini berupa pengembangan permainan ludo king of accounting yang digunakan untuk media pengayaan terkait materi jurnal khusus perusahaan dagang. Penelitian ini menggunakan model ADDIE yang meliputi tahap analisis, perancangan, dan tahap pengembangan. Namun, terdapat dua tahap yang tidak dilaksanakan dalam penelitian ini dikarenakan kondisi tertentu dan keterbatasan waktu yaitu tahap implementasi dan evaluasi.

Tahap yang pertama kali dilakukan ialah tahap analisis. Dimulai dari analisis kinerja yang dilaksanakan dengan tujuan untuk mencari informasi, mengetahui, dan mendefinisikan situasi atau masalah yang sedang terjadi. Kemudian menganalisis situasi tersebut dan mencari solusi untuk mengatasi masalah yang terjadi. Berdasarkan hasil analisis kinerja, maka selanjutnya akan dilaksanakan analisis kebutuhan terkait pemecahan atau jalan keluar yang digunakan untuk mengatasi masalah tersebut dan ketertarikan guru serta peserta didik terhadap suatu produk yang dikembangkan, yaitu media permainan ludo king of accounting sebagai media pengayaan. Kemudian melakukan perumusan tujuan pembelajaran yang akan dicapai sesuai dengan Standar Kompetensi Dasar dan Indikator yang digunakan.

$$
\text { p-ISSN 2337-571X | e-ISSN 2541-562X }
$$

(C) 2020 Edunomic: Jurnal Ilmiah Pendidikan Ekonomi Fakultas Keguruan dan Ilmu Pendidikan 
Kedua, tahap selanjutnya adalah melakukan perancangan media permainan ludo king of accounting. Dalam membuatan rancangan media permainan ludo king of accounting meliputi kegiatan merancang rumusan butir soal latihan terkait jurnal khusus perusahaan dagang dan komponen yang ada dalam media permainan ludo king of accounting. Komponen tersebut terdiri dari papan permainan dalam bentuk cetak berukuran 40x40 $\mathrm{cm}$ yang memiliki 4 warna, yaitu warna merah, kuning, hijau, dan biru. Kemudian beberapa kartu soal dengan warna biru, kartu jawaban warna hijau, kartu permainan warna merah yang menandakan kartu zonk, dan warna kuning yang menandakan kartu reward. Semua jenis kartu berukuran $6 \times 11 \mathrm{~cm}$. Selain itu terdapat perancangan untuk desain packaging produk yang berukuran $20 \mathrm{x} 40 \mathrm{~cm}$ dengan sistem buka tutup.

Selanjutnya tahap terakhir ialah tahap pengembangan. Produk awal yang telah dirancang pada tahap sebelumnya akan diwujudkan dan diproduksi. Setelah selesai diproduksi, kemudian akan dilakukan telaah materi dan media. Hasil telaah dari para ahli materi dan media dalam bentuk saran dan masukan yang akan digunakan sebagai pedoman dalam melakukan revisi produk yang dikembangkan. Setelah media permainan ludo king of accounting direvisi, media akan dikirimkan kembali kepada para ahli untuk ditelaah ulang dan jika sudah sesuai, produk permainan ludo king of accounting akan divalidasi berdasarkan kelayakannya sebagai media pengayaan pada materi jurnal khusus perusahaan dagang. Adapun hasil persentase validasi yang diperoleh dari ahli materi dan media disajikan dalam tabel berikut:

Tabel 3. Hasil Validasi Ahli Materi

\begin{tabular}{cccc}
\hline No. & Komponen Kelayakan & Persentase & Kriteria \\
\hline 1. & Kualitas isi dan tujuan & $88,75 \%$ & Sangat Layak \\
2. & Kualitas instruksional & $86,67 \%$ & Sangat Layak \\
& Rata-rata & $\mathbf{8 7 , 7 1 \%}$ & Sangat Layak \\
\hline
\end{tabular}

Sumber: data diolah peneliti (2020)

Tabel 4. Hasil Validasi Ahli Media

\begin{tabular}{cccc}
\hline No. & Komponen Kelayakan & Persentase & Kriteria \\
\hline 1. & Kualitas teknis & $88 \%$ & Sangat layak \\
\hline
\end{tabular}

Sumber: data diolah peneliti (2020)

\section{Pembahasan}

\section{Proses Pengembangan Permainan Ludo King of Accounting (Doting) sebagai Media Pengayaan pada Materi Jurnal Khusus Perusahaan Dagang}

Proses pengembangan dilakukan dengan mengimplementasikan tahap analisis, perancangan, dan tahap pegembangan yang ada dalam model pengembangan ADDIE. Tahap implementasi dan evaluasi tidak dilaksanakan dikarenakan kondisi tertentu dan keterbatasan waktu. Sehingga terbatas pada tahap pengembangan.

Tahap pertama ialah melakukan analisis kinerja untuk mengetahui media yang biasa digunakan di kelas saat melaksanakan kegiatan pengayaan. Dalam melaksanakan kegiatan pengayaan, media yang sering digunakan berupa fasilitas kelas seperti LCD-powerpoint, papan tulis, dan foto copy soal pengayaan yang diperoleh dari guru. Belum ada pemanfaatan media 
yang bervariatif dalam menunjang kegiatan pengayaan. Sehingga peserta didik merasa jenuh, kurang antusias, dan sibuk berbicara sendiri dengan temannya ketika kegiatan pengayaan berlangsung. Hal ini yang menyebabkan fokus peserta didik terpecah dan memiliki motivasi rendah dalam melaksanakan kegiatan pengayaan.

Selanjutnya adalah analisis kebutuhan berdasarkan situasi yang diketahui dari hasil analisis kinerja yang sudah dilakukan. Dalam analisis kebutuhan, dibutuhkan suatu media yang inovatif dan menarik untuk menunjang kegiatan pengayaan agar guru dapat meningkatkan motivasi dan semangat peserta didik ketika melaksanakan kegiatan pengayaan. Media pengayaan berupa permainan ludo king of accounting dapat dijadikan sebagai alternatif dalam menunjang kegiatan pengayaan. Dengan adanya media permainan ludo king of accounting, peserta didik dapat tetap melakukan pembelajaran sambil bermain. Hal ini dapat menciptakan suatu kondisi belajar dengan lebih seru, menantang, dan tidak membosankan. Selain itu, ketika mengerjakan soal pengayaan dengan cara berkompetesi dalam permainan ludo king of accounting akan menjadikan peserta didik lebih bersemangat. Analisis selanjutnya yaitu merumuskan tujuan pembelajaran yang mengacu dan sesuai dengan kompetensi dasar dan indikator materi jurnal khusus perusahaan dagang.

Tahap yang kedua ialah tahap perancangan. Dalam tahap ini, dibuat rancangan butirbutir soal pengayaan terkait materi jurnal khusus perusahaan dagang yang sesuai dengan perumusan tujuan pembelajaran dan berpedoman pada kurikulum yang berlaku. Kemudian, peneliti membuat rancangan awal media permainan ludo king of accounting yang meliputi desain papan permainan, kartu soal, kartu jawaban, kartu zonk, kartu reward, dan desain untuk packagingnya. Semua desain media permainan ludo king of accounting dirancang dengan menggunakan aplikasi yang berasal dari komputer berupa coreldraw X7.

Terakhir ialah tahap pengembangan. Pada tahap akhir ini dilakukan penyusunan dan memproduksi media permainan ludo king of accounting sesuai dengan hasil rancangan pada tahap sebelumnya menjadi produk jadi. Media yang telah diproduksi tersebut akan diberikan kepada ahli materi dan media untuk di telaah. Hasil dari proses telaah materi dan media yang dilakukan berupa saran dan masukan yang akan dijadikan sebagai pedoman dalam merevisi media tersebut. Setelah direvisi, produk akan dikirimkan kembali kepada para ahli untuk ditelaah dan divalidasi sesuai dengan kelayakan produk permainan ludo king of accounting hingga media layak untuk digunakan pada kegiatan pengayaan jurnal khusus perusahaan dagang.

\section{Kelayakan Permainan Ludo King of Accounting (Doting) sebagai Media Pengayaan pada Materi Jurnal Khusus Perusahaan Dagang}

Kelayakan media permainan ludo king of accounting dilihat berdasarkan hasil validasi para ahli materi dan media. Validasi materi pertama dilakukan oleh ibu Dra. Heny Pudjiastuti, MM., selaku guru yang berpengalaman mengajar Akuntansi di SMK Negeri 1 Sooko Mojokerto. Validasi materi selanjutnya dilakukan oleh bapak Drs. Joni Susilowibowo, M.Pd., selaku dosen Pendidikan Akuntansi Universitas Negeri Surabaya. Berdasarkan hasil telaah yang dilakukan, soal pengayaan terkait materi jurnal khusus perusahaan dagang belum mencakup jurnal khusus dengan metode perpetual dan penulisan nama akun harus disesuaikan dengan pedoman terbaru sehingga diperlukan adanya revisi. Setelah dilakukan revisi, ahli materi mengatakan soal pengayaan terkait jurnal khusus perusahaan dagang sudah sesuai dan dilakukan validasi oleh para ahli materi. Hasil persentase validasi dari para ahli materi menunjukkan nilai sebesar $88,75 \%$ dilihat berdasarkan kualitas isi dan tujuan, $86,67 \%$ 
berdasarkan kualitas instruksional, dan $87,71 \%$ yang merupakan rata-rata hasil persentase validasi dengan kategori sangat layak berdasarkan kedua kualitas tersebut.

Menurut Arsyad (2017) suatu materi dapat dinilai berdasarkan kualitas isi dan tujuan yang meliputi seluruh aspek keakuratan, kegunaan, kelengkapan, minat dan perhatian, keseimbangan, dan kesesuaian situasi peserta didik. Selain itu, berdasarkan kualitas instruksional dapat dilihat melalui aspek kesempatan belajar yang diberikan, dukungan belajar, karakteristik memotivasi, fleksibilitas instruksional, hubungannya dengan kegiatan pembelajaran lainnya, interaksi sosial instruksional, kualitas tes dan penilaian, dampak bagi peserta didik dan guru. Menurut Riduwan (2012) hasil persentase dalam rentang 81\%-100\% memiliki kriteria interpretasi sangat layak. Sehingga, dari hasil persentase validasi materi yang diperoleh sebesar $87,71 \%$, soal pengayaan terkait jurnal khusus perusahaan dagang dinyatakan sangat layak.

Validasi berikutnya yaitu validasi media permainan ludo king of accounting yang dilakukan oleh ibu Dr. Utari Dewi, S.Sn., M.Pd., selaku dosen jurusan Kurikulum dan Teknologi Pendidikan Universitas Negeri Surabaya. Berdasarkan hasil telaah yang dilakukan, gambar karakter wanita dalam desain papan permainan kurang sesuai dan kalimat keterangan pada packaging bagian pojok kiri bawah kurang terlihat jelas dikarenakan warna font yang pudar, sehingga diperlukan adanya revisi. Setelah dilakukan revisi, ahli media mengatakan desain permainan ludo king of accounting sudah sesuai dan dilakukan validasi oleh ahli media. Hasil persentase validasi yang diperoleh berdasarkan kualitas teknis sebesar $88 \%$, persentase tersebut dalam kategori sangat layak.

Menurut Arsyad (2017) kualitas teknis meliputi seluruh aspek keterbacaan, kualitas tampilan, pengelolaan program, pendokumentasian, dan kemudahan dalam penggunaannya. Menurut Riduwan (2012), hasil persentase validasi dalam rentang 81\%-100\% memiliki kriteria interpretasi sangat layak. Sehingga, hasil persentase sebesar $88 \%$ yang diperoleh dari ahli media menunjukkan bahwa permainan ludo king of accounting dalam kategori interpretasi sangat layak digunakan untuk media pengayaan jurnal khusus perusahaan dagang.

Kelayakan permainan ludo king of accounting jenis board game ini juga didukung oleh beberapa penelitian terdahulu yaitu penelitian yang dilakukan oleh Aliatin (2016) yang menyatakan bahwa permainan jenis board game sangat layak digunakan sebagai media pengayaan dengan persentase hasil kelayakan sebesar $89,75 \%$ dan penelitian sejenis juga yang dilakukan oleh Lestari (2018) yang menyatakan bahwa permainan jenis board game dalam bentuk cetak dinyatakan sangat layak digunakan sebagai media dalam menunjang kegiatan pengayaan dengan persentase hasil kelayakan sebesar $86,15 \%$.

\section{Simpulan}

Berdasarkan hasil pembahasan di atas, simpulan dari penelitian tersebut yaitu 1) Proses pengembangan permainan ludo king of accounting sebagai media pengayaan pada materi jurnal khusus perusahaan dagang menggunakan model ADDIE yang terdiri dari tahap analisis, perancangan, dan tahap pengembangan. Tahapan penelitian dilakukan hanya sampai pada tahap pengembangan yang dikarenakan kondisi tertentu dan keterbatasan waktu, sehingga tahap implementasi dan evaluasi tidak dilakukan. Setelah melalui tiga tahapan yang dilakukan, diperoleh hasil media pengayaan jurnal khusus perusahaan dagang berupa permainan ludo king of accounting. 2) Kelayakan media pengayaan permainan ludo king of accounting diketahui berdasarkan perhitungan hasil validasi dari para ahli. Hasil persentase validasi dari ahli materi menunjukkan kategori sangat layak. Dengan demikian, permainan ludo king of

$p-I S S N \underline{2337-571 X} \mid e-I S S N \underline{2541-562 X}$

(C) 2020 Edunomic: Jurnal Ilmiah Pendidikan Ekonomi Fakultas Keguruan dan Ilmu Pendidikan 
accounting sangat layak digunakan sebagai media pengayaan jurnal khusus perusahaan dagang.

\section{Referensi}

Angguntari, Y. P. (2019). Pengembangan Papan Permainan Ludo sebagai Media Pembelajaran untuk Meningkatkan Hasil Belajar pada Kompetensi Dasar Menganalisis Persyaratan Personil Administrasi Kelas X OTKP di SMK Negeri 10 Surabaya. Pendidikan Administrasi Perkantoran, Vol.7 No.3, 43-50.

Arsyad, A. (2017). Media Pembelajaran. Jakarta: Rajawali Pers.

Hamalik, O. (2015). Kurikulum dan Pembelajaran. Jakarta: PT Bumi Aksara.

Hamalik, O. (2016). Proses Belajar Mengajar. Jakarta: PT Bumi Aksara.

Jannah, M. M., \& Wiyatmo, Y. (2018). Pengembangan Media Pembelajaran Permainan Ludo untuk Meningkatkan Penguasaan Materi dan Minat Belajar Fisika Peserta didik SMA. Jurnal Pendidikan Fisika, 240-249.

Khodizah, S. (2019). Development od Ludo Game as Learning Media in Circular Motion. Jurnal Pembelajaran Fisika, Vol.7(September), 19-27.

Molenda, M. (2003). In Search of the Elusive ADDIE Model. (June), 1-4. Retrieved from https://www.danapayne.net/uploads/5/9/7/7/59770463/insearchofelusiveaddie.pdf

Nasution. (2012). Kurikulum dan Pengajaran. Jakarta: PT Bumi Aksara.

Ningsih, S. A., \& Pritandhari, M. (2019). Pengembangan Media Pembelajaran Ludo pada Mata Pelajaran Ekonomi Kelas XI SMA Purnama Trimurjo. Jurnal Pendidikan Ekonomi, Vo.7 No.1(1), 50-59.

Permendikbud No. 22 Tahun 2016 Tentang Standar Proses Pendidikan Dasar dan Menengah. (n.d.).

Permendikbud No. 23 Tahun 2016 Tentang Standar Penilaian Pendidikan. (n.d.). https://doi.org/10.1017/CBO9781107415324.004

Rahman, M., \& Amri, S. (2013). Strategi \& Desain Pengembangan Sistem Pembelajaran. Jakarta: Prestasi Pustakaraya.

Riduwan. (2012). Skala Pengukuran Variabel-Variabel Penelitian. Bandung: Alfabeta.

Sadiman, Arief S., dkk. (2011). Media Pendidikan (Pengertian, Pengembangan, dan Pemanfaatannya). Jakarta: PT. Raja Grafindo Persada.

Sakinah, \& Iswendi. (2018). Pengembangan Ludo Word Game sebagai Media Pembelajaran pada Materi Minyak Bumi Kelas XI SMA. Jurnal Pendidikan Kimia, Vol.12 No.(12), $58-69$.

Tiarto, E. H., Suyatna, A., \& Sesunan, F. (2013). Pengembangan Permainan Edukatif Materi Hukum Gravitasi Newton. Scientific Messenger of LNU of Veterinary Medicine and Biotechnology, 18(3(70)), 8-13.

Undang-Undang Nomor 20 Tahun 2003 Pasal 1 Ayat (1) tentang Sistem Pendidikan Nasional. (n.d.).

Yolanda, N. S., \& Iswendi. (2019). Pengembangan Permainan Ludo Kimia Sebagai Media Pembelajaran Pada Materi Bentuk Molekul Kelas X SMA / MA. Jurnal Pendidikan Kimia, 1(3), 9-14. 